\title{
Edukacja w perspektywie inkontrologii. Spotkanie jako kategoria pedagogiczna
}

\section{Uwagi wstępne}

We wszelkich aktach edukacyjnych podmioty komunikują się ze sobą. To oczywiście truizm, ale warto jednak zauważyć, że zarówno edukacja, jak i komunikowanie są pojęciami „wielowymiarowymi”, co rodzi różne możliwości analizy wzajemnych relacji.

Mówiąc o edukacji warto traktować ją najszerzej, a nie ograniczać jej tylko do kształcenia szkolnego czy akademickiego. Za Zbigniewem Kwiecińskim przyjmuję bardzo szerokie rozumienie edukacji, jako kategorii obejmującej wszystkie szczegółowe procesy rozwoju, wychowania, wpływu i oddziaływania na zmianę osobowości, kategorii rozumianej jako „(...) ogół czynności prowadzenia drugiego człowieka i jego własnej aktywności w osiąganiu pełnych i swoistych dlań możliwości, jak też ogół wpływów i funkcji ustanawiających i regulujących osobowość człowieka i jego zachowanie w relacji do innych ludzi i wobec świata".

Dodatkowo warto pamiętać o - funkcjonującym nie tylko w tekstach pedagogicznych, ale nawet w aktach prawnych ${ }^{2}$ - wyróżnieniu trzech

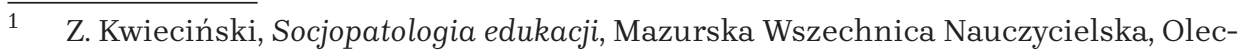
ko 1995, s. 14.

2 Zob. np. ustawa z dnia 22 grudnia 2015 r. o Zintegrowanym Systemie Kwalifikacji (Dz.U. 2016, poz. 64, z późn. zm.), s. 2. 
rodzajów - pojmowanej jako całożyciowa (lifelong education) - edukacji: formalnej, pozaformalnej i nieformalnej. Ta pierwsza (formal education) to zorganizowana działalność mająca miejsce w szkołach wszystkich szczebli i uczelniach wyższych, ta druga (non-formal education) to - w uproszczeniu - różne kursy i inne formy zorganizowanego dokształcania, edukacja nieformalna (informal education) to uczenie się poprzez doświadczenie i korzystanie $\mathrm{z}$ wychowawczych wpływów swojego środowiska: rodziny i sąsiadów, pracy i rozrywki, środków przekazu ${ }^{3}$. W wielu opracowaniach termin „edukacja nieformalna” został zastąpiony terminem „uczenie się nieformalne” (informal learning), ponieważ ta edukacja odbywa się bez nauczycieli i w istocie sprowadza się do samodzielnego - chociaż najczęściej nieświadomego i nieintencjonalnego - uczenia się.

Mówiąc o komunikacji w edukacji zazwyczaj mamy na myśli komunikowanie się bezpośrednie - twarzą w twarz - w rozmaitych układach: nauczyciel z pojedynczym uczniem, nauczyciel z grupą uczniów, uczniowie bądź nauczyciele między sobą, nauczyciel z rodzicami - jeśli ograniczyć się tylko do edukacji szkolnej. Jeśli zaś używać terminu „edukacja” w znaczeniu szerokim, zwłaszcza gdy skupimy się na edukacji nieformalnej, to pojawia się jeszcze wiele innych możliwości komunikowania, m.in.: wszystkich członków rodziny pomiędzy sobą, pracownika z pracodawcą, pracowników między sobą, uczestnika zebrania czy zgromadzenia $\mathrm{z}$ innymi uczestnikami, sąsiada z sąsiadem, pacjenta z personelem szpitala, petenta z urzędnikiem, członka stowarzyszenia z innymi członkami i wiele innych. Jednakże oprócz komunikowania się bezpośredniego istnieje inny rodzaj komunikacji, która również ma duże znaczenie pedagogiczne - komunikacji człowieka z autorem dzieła, za jego pośrednictwem. Naturalnie można rozważać dzieła różnego rodzaju: muzyczne, plastyczne, teatralne czy filmowe, jak się jednak wydaje najważniejsze znaczenie dla edukacji mają dzieła w postaci tekstów (niekoniecznie tylko drukowanych, również tych dostępnych w Internecie). W tym kontekście mieszczą się również prawie wszystkie kontakty z dziełami (bądź z „dziełami”), mające postać zwyczajnego korzystania z mass mediów.

3 Zob. M. Malewski, Od nauczania do uczenia się. O paradygmatycznej zmianie w andragogice, Wydawnictwo Naukowe Dolnośląskiej Szkoły Wyższej, Wrocław 2010, s. 21. 
Rozważania nad komunikacją międzyludzką, w tym również w edukacji, prowadzone są zwykle za pomocą takich m.in. terminów, jak: rozmowa, dialog, dyskurs, komunikacja bezpośrednia i pośrednia, werbalna i niewerbalna, wpływ, modelowanie, manipulacja, indoktrynacja i wiele innych, mniej lub bardziej pozytywnie wartościowanych. Stawiam tezę, że interesujące możliwości analizy komunikacyjnych procesów edukacyjnych niesie termin „spotkanie”.

\section{Inkontrologia - najważniejsze ustalenia}

Inkontrologia - jako ogólna teoria spotkań - została zaprojektowana przed ponad czterdziestu laty i rozwijana przez kolejne dziesięciolecia przez lubelskiego filozofa Andrzeja Nowickiego ${ }^{4}$, w każdym razie on jest pomysłodawcą terminu. Nazwa pochodzi od włoskiego słowa inkontro, które oznacza spotkanie bądź zderzenie. Nowicki nie był wszakże jedynym myślicielem, który zajmował się spotkaniem, należy odnotować również wkład innych, w szczególności Jerzego Bukowskiego $^{5}$. Trzeba przy tym podkreślić, że o ile Nowicki rozwijał inkontrologię z perspektywy materialistycznej i ateistycznej, to Bukowski czynił to $\mathrm{z}$ pozycji personalizmu chrześcijańskiego. Nowicki koncentruje się na spotkaniu z dziełami, nie traktując pozostałych odmian spotkania jako mniej ważne, uznaje je jednak za pochodne. Natomiast Bukowski mówi wyłącznie o spotkaniach między ludźmi. Tych różnic jest więcej, warto więc zaprezentować koncepcje obu myślicieli nieco szczegółowiej.

Według Nowickiego poprzez kontakt z dziełem zachodzi spotkanie (pośrednie) z jego autorem, dodatkowo np. lektura może zainspirować czytelnika do bezpośredniego kontaktu z autorem (jeśli autor żyje i ma na ten kontakt ochotę) lub przynajmniej z innymi odbiorcami równie zainspirowanymi i skłonnymi do wymiany uwag; ważne lektury pobudzają też zwykle do refleksji, a więc swoistego spotkania się z samym sobą. Tym samym inkontrologia w ujęciu jej twórcy to przede wszystkim spotkanie z dziełami (głównie - choć nie tylko - tekstami).

$4 \quad$ Zob. A. Nowicki, Spotkania w rzeczach, PWN, Warszawa 1991. Pewne zarysy koncepcji można dostrzec już w znacznie wcześniejszej książce autora, zob. Idem, Człowiek w świecie dzieł, PWN, Warszawa 1974.

$5 \quad$ Zob. J. Bukowski, Zarys filozofii spotkania, Wydawnictwo Znak, Kraków 1987. 
Spotkanie „w rzeczach”, jak to określa, Nowicki uważa zresztą za bardziej wartościowy rodzaj spotkania niż spotkanie „poza rzeczami”. Jest tak z trzech powodów: 1) w rzeczach spotyka się najwartościowsze aspekty danej osoby, 2) w rzeczach można się spotkać z osobami z innych epok i innych części świata, 3) w rzeczach można się spotkać jednocześnie z olbrzymią liczbą ludzi ${ }^{6}$.

Najbardziej charakterystyczną cechą ludzkiej osobowości i specyficznie ludzkim sposobem istnienia w świecie jest wielocząstkowość - zespalanie w jedną, mniej lub bardziej zintegrowaną, strukturę istotnych cząstek osobowości spotkanych ludzi, spotkanych bezpośrednio lub w dziełach. Owa policentryczna struktura osobowości powoduje wytwarzanie się w świecie wewnętrznym pola napięć, które mogą być motorem działań twórczych? . Nowicki posuwa się do swoistego przeniesienia akcentów dotyczących definiowania istoty człowieka: „Izolowana od wszystkich spotkań z innymi ludźmi jednostka traci własne człowieczeństwo, ponieważ specyficznie ludzki sposób istnienia polega właśnie na ciągłych spotkaniach z innymi ludźmi i urzeczywistnia się wyłącznie w koegzystencji i współobecności czyli w życiu społecznym”. A także: „To nie jest tak, że poszczególni ludzie (o już ukształtowanej osobowości i indywidualnej egzystencji) spotykają się i wytwarzają "spotkania", ale odwrotnie, najpierw zachodzą spotkania, dzięki którym człowiek staje się człowiekiem, rosnąc, rozwijając się i wyodrębniając się swoją odmiennością od innych ludzi"9. I wreszcie najważniejsza konkluzja: „to, co nazywamy podmiotem, jest - w swojej istocie i strukturze - wytworem spotkań"10.

Żadne spotkanie nie zaczyna się od „zera”, aby się spotkać, trzeba już być jakoś ukształtowanym. W każde spotkanie podmiot wnosi historię swoich wcześniejszych spotkań. Ta historia ujawnia się jako dynamiczny układ czterech rodzajów „mas”: 1) mas apercepcyjnych - ogółu naszej wiedzy i zainteresowań, które wpływają na to, co w spotkaniu zostanie dostrzeżone; 2) mas plastycznych - składników osobowości, które jeszcze „nie zastygły” i są podatne na modyfikacje,

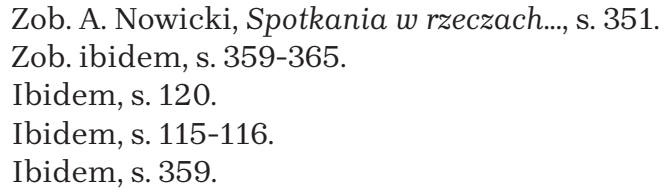


pod warunkiem otwarcia się na oddziaływanie partnera; 3) mas obronnych - zespołu mechanizmów nastawionych na utrwalanie aktualnej tożsamości (gdyby ich nie było, każde spotkanie całkowicie by nas zmieniało); 4) mas emanacyjnych - tych składników osobowości, które mogą zadziwiać, fascynować partnera i wywierać na niego wpływ. Inkontrologia w ujęciu Nowickiego zakłada, że spotkania nie muszą być zaskakujące i nieprzewidziane, przeciwnie - zakłada możliwość projektowania, planowania, organizowania i optymalnego wykorzystania spotkań. W szczególności możliwe jest przygotowywanie się do spotkania; odnosząc się do czterech rodzajów „mas”: 1) należy wzbogacać własne masy apercepcyjne: rozbudzać zainteresowania, poszerzać i pogłębiać wiedzę; 2) należy dbać, by nasza osobowość „nie zastygła”, zachować plastyczność i podatność na przekształcanie, otwierać się na nowości; 3) należy uruchamiać krytycyzm podczas recepcji treści zewnętrznych, stosować swoiste filtry, które nie dopuszczą do zniszczenia już istniejących, wartościowych składników osobowości; 4) podczas spotkania należy pobudzać masy emanacyjne partnera, by jak najwięcej wynieść ze spotkania. Nowicki bardzo mocno akcentuje, że nad spotkaniami można i trzeba prowadzić systematyczną refleksję, że do spotkań należy się przygotowywać oraz że spotkania można wykorzystać praktycznie, w tym również edukacyjnie.

Bukowski ma zasadniczo inne podejście. Inkontrologia może rozpatrywać spotkania między człowiekiem i rzeczami, bądź spotkania między ludźmi poprzez rzeczy, jednakże sam autor, niechętny terminowi inkontrologia, jest zdania, że „spotkanie jest wydarzeniem, które może zachodzić tylko pomiędzy osobami"11. Mówi nie tyle o teorii czy nauce o spotkaniach, co raczej o filozofii spotkań, traktowanej w kategoriach niemal metafizycznych. Definicja spotkania według tego myśliciela jest następująca: „Spotkanie to nagłe, nieredukowalne, wzajemne, emocjonalne, niedyskursywne, bezpośrednie otwarcie się dla siebie dwóch osób; odczuwają one łączność ze sobą, przejawiającą się poczuciem niezastępowalności drugiej osoby oraz aksjologiczne i moralne "przewyższenie siebie"w obliczu tajemnicy Absolutu" ${ }^{2}$.

Nagłość oznacza, że spotkanie wydarza się niespodziewanie, stanowiąc zaskoczenie; ma miejsce spontaniczność, często porażenie,

11 J. Bukowski, Zarys filozofii spotkania..., s. 16.

12 Ibidem, s. 154. 
oszołomienie. Nieredukowalność oznacza, że spotkania nie da się sprowadzić do żadnych innych form kontaktów międzyludzkich. Wzajemność oznacza, że oddziałują na siebie obaj partnerzy spotkania, chociaż niekoniecznie w równym stopniu. Emocjonalność to nadanie spotkaniu właściwego charakteru przez emocje, bez których byłby to jedynie jakiś wariant wzajemnego poznawania się; $\mathrm{w}$ „emocjonalnym czuciu" dane są wartości, zaś w spotkaniu chodzi właśnie o realizację jakichś wartości. Niedyskursywność to zarówno niemożność przekazania istoty spotkania innym osobom, ale również częsty brak w spotkaniu jakichkolwiek słów. Bezpośredniość - związana z niedyskursywnością - oznacza brak pośredniości przede wszystkim poznawczej; w spotkaniu dany jest w pełni drugi człowiek, a nie tylko jego obraz czy wizja. Otwarcie się osób dla siebie zakłada wzajemną rozporządzalność, zaufanie, zawierzenie się drugiemu, odkrycie się przed drugą osobą. Łączność ze sobą oznacza chęć pozostawania jak najdłużej w osobowym zespoleniu. Niezastępowalność partnera oznacza postawę: „tylko ty, nikt inny”. Przewyższenie siebie oznacza poczucie moralnej siły oraz zainicjowanie dążenia ku najwyższym wartościom w przyjętym przez siebie ich systemie ${ }^{13}$.

Bukowski wymienia możliwe efekty spotkania, dzieląc je na aksjologiczno-moralne i epistemologiczne. Aksjologiczno-moralne efekty to: 1) miłość; 2) odwaga realizacji tego, co słuszne; 3) odczucie jedności samego siebie; 4) przywrócenie wiary w ludzi, w sens życia, we własne człowieczeństwo; 5) pokora; 6) szacunek dla osoby; 7) rozpoznanie wolności; 8) odpowiedzialność; 9) odsłonięcie metafizycznego wymiaru ludzkiego bytu. Epistemologiczne efekty spotkania to: 1) rozumienie drugiej osoby aż do granic sfery intymnej; 2) rozumienie siebie; 3) rozumienie wartości; 4) naukowy zapał (chęć zdobywania wiedzy, problematyzowanie spraw dotąd nieproblematycznych $)^{14}$.

Bukowski swoją filozofię spotkań buduje-czego nie ukrywa-na bazie filozofii dialogu, przede wszystkim Martina Bubera i Emmanuela Lévinasa. Tym samym ma miejsce swoista koincydencja pojęć „spotkanie” i „dialog”. Analizująca istotę dialogu Genowefa Koć-Seniuch akcentuje fakt, że on również może przybrać formę spotkania, które tym samym staje się niejako inną (wyższą?) formą dialogu. „Spotkać, to coś

3 Zob. ibidem, s. 154-168.

14 Zob. ibidem, s. 265-307. 
więcej niż mieć świadomość, że Inny jest obecny obok mnie. Spotkać, to wykraczać poza siebie, to doświadczać Innego"15. W innym miejscu stwierdza wszakże - dialog jest najbardziej dojrzałą formą kontaktu międzyludzkiego ${ }^{16}$. Jego wartość - za Gadamerem - autorka dostrzega głównie w tym, że umożliwia on kształtowanie postawy otwartej wobec Innego, „rozumiejący” ogląd rzeczy i relacji międzyludzkich ${ }^{17}$. Nowicki - pozornie dystansujący się od „osobowego” pojmowania spotkania - również podkreśla wartość dialogu. Dialog jest według niego wspólnym, wielopodmiotowym działaniem, mającym w zamierzeniu wytworzyć coś nowego - jednakże jedynie wtedy, gdy jego uczestnicy chcą i są w stanie wnieść do spotkania coś własnego, co dla innych może okazać się cenne ${ }^{18}$.

Z innych myślicieli, którzy poddali namysłowi istotę spotkania warto jeszcze wziąć pod uwagę myśli Józefa Tischnera, Tadeusza Gadacza i Urszuli Ostrowskiej. W koncepcji Tischnera, podobnie jak u Bukowskiego, spotkanie jest pojmowane jako warunek wejścia człowieka w świat wartości, ponieważ wchodząc w relację z drugim człowiekiem przede wszystkim bezpośrednią, ale też, w jakimś stopniu, zapośredniczoną przez teksty - wchodzi się jednocześnie w relację z wartościami: „Przeżywając spotkanie, wiemy w sposób pewny: drugi jest inny, jest transcendentny. Wiemy również coś więcej: on i ja znajdujemy się w przestrzeni dobra i zła, wartości i antywartości. Mogę dotknąć drugiego, skrzywdzić go, mogę mu przynieść radość. Podobnie on”19.

W centrum spotkania Tischner stawia zadawanie pytań. Jest tak dlatego, że zapytana osoba wychodzi ze swej „sobości”, ze swej zamkniętej podmiotowości, osobności. Pytanie ma moc rozbijania zamkniętego monadycznego świata jednostki, daje szansę przeniesienia się ze świata jednego człowieka w świat drugiego ${ }^{20}$. Tu warto zauważyć, że tego typu pytanie może nam „zadać” również czytany tekst czy

$\overline{15}$ G. Koć-Seniuch, Dialog, [w:] T. Pilch (red.), Encyklopedia pedagogiczna XXI wieku, t. 1, Wydawnictwo Akademickie Żak, Warszawa 2003, s. 690.

16 Zob. ibidem, s. 688.

17 Zob. ibidem, s. 690.

18 Zob. A. Nowicki, Spotkania w rzeczach..., s. 414.

19 J. Tischner, Myślenie według wartości, Wydawnictwo Znak, Kraków 2000, s. 482-483.

20 Zob. P. Walczak, Wychowanie jako spotkanie. Józefa Tischnera filozofia człowieka jako źródło inspiracji pedagogicznych, Oficyna Wydawnicza „Impuls”, Kraków 2007, s. $122-123$. 
oglądany film albo spektakl - a nie tylko druga osoba w bezpośrednim dialogu.

Podstawowe terminy, za pomocą których Tischner opisuje tworzoną przez siebie antropologię, to: ja aksjologiczne, osoba, wolność, nadzieja, spotkanie i dobro. Zdaniem Pawła Walczaka, jednego z myślicieli zajmujących się dorobkiem Tischnera i umieszczającego go w kontekście pedagogicznym, mogą one stanowić dobre narzędzia do opisu procesu wychowania, a także projektowania oddziaływań wychowawczych, wywiedzionych z koncepcji tak zwanego człowieka agatologicznego - człowieka, który dopiero się staje, który jest niedokończony, niepełny, który nieustannie się tworzy ${ }^{21}$. I właśnie spotkania mogą być znaczącym elementem owego tworzenia się podmiotu, co zresztą wydaje się w pełni zgodne z tezą Nowickiego, iż każdy z nas jest tak naprawdę „wytworem spotkań” - jak to było cytowane.

Tadeusz Gadacz postrzega spotkanie - oprócz innych jego aspektów - jako najlepsze remedium na kryzys wychowania we współczesnej szkole. Pisze:

Kryzys szkoły jest (...) kryzysem osobowym. Oznacza to najpierw, że szkoła przestała być wspólnotą nauczycieli, jako mistrzów, i uczniów, wspólnotą, w której dokonuje się edukacja: gdzie wychowawca jako mistrz już idący drogą ku prawdzie, dobru i pięknu, prowadzi ze sobą wychowanków i dzięki nim także sam niejednokrotnie do prawdy, dobra i piękna się zbliża. Po wtóre, symptomem kryzysu szkoły jest utrata sensu takiego słowa jak edukacja. Szkoła nie dokonuje edukacji, a jedynie uczy i przekazuje wiedzę. Szkoła nie wychowuje, to znaczy nie odsłania dobra, prawdy i piękna i nie pociąga do urzeczywistnienia wartości. A jeśli wychowuje, to jedynie w znaczeniu przystosowywania do obowiązujących struktur i instytucjonalnych modeli życia ${ }^{22}$.

Autor podkreśla, że chodzi o spotkanie OSÓB, a nie jest łatwo być osobą. Wymaga to m.in. otwarcia się na wartości, ale także swoistego balansowania między możliwymi skrajnościami: między ucieczką w wewnętrzność a całkowitym otwarciem się na zewnątrz, między

21 Zob. ibidem, s. 139.

22 T. Gadacz, Wychowanie jako spotkanie osób, [w:] F. Adamski (red.), Człowiek, wychowanie, kultura. Wybór tekstów, Wydawnictwo WAM, Kraków 1993, s. 107. 
indywidualizmem a kolektywizmem ${ }^{23}$. Rozróżnia wychowanie w optyce funkcjonowania i wychowanie w optyce spotkania osób. To pierwsze sprowadza się do przedmiotowego traktowania wychowanka i w istocie do jego urabiania, to drugie ,jest spotkaniem osób, mistrza i ucznia, poprzez które otwiera się horyzont wartości, dzięki którym człowiek staje się człowiekiem, bez względu na ideologię czy system społeczny”24. W konkluzji: „Dla wychowawcy, który jest osobą i wychowuje osoby, każda chwila jest inna, odmienna, jak odmienna jest każda osoba i każda chwila oraz sytuacja jej życia. Wychowanie osobowe jest wciąż otwartą możliwością spotkania, zmiany i nawrócenia"25.

Według tego autora - piszącego z perspektywy personalizmu chrześcijańskiego - spotkanie jest w oczywisty sposób spotkaniem osób, co przede wszystkim stoi w sprzeczności z wszelkimi przejawami standaryzacji oraz uprzedmiotowienia.

Według Urszuli Ostrowskiej w obszarze zainteresowania inkontrologii można wyróżnić trzy rodzaje spotkań: 1) z kimś, 2) z czymś głównie - z dziełem, 3) z samym sobą ${ }^{26}$. Ten ostatni rodzaj może się wydawać zaskakujący, ale warto zwrócić uwagę, że Ostrowska podjęła się próby rozwijania nie inkontrologii w ogóle, lecz inkontrologii pedagogicznej. Jeśli we współczesnej edukacji podkreśla się jako ważne aspekty: samowychowanie, samokształcenie, samorozwój, to w każdym takim przypadku niezbędna jest autorefleksja, czyli w zasadzie pewnego typu spotkanie z samym sobą. Tymczasem, zdaniem autorki, ten ostatni rodzaj spotkania jest szczególnie trudny dla współczesnego człowieka, żyjącego w świecie, w którym ,jest coraz więcej informacji, a coraz mniej znaczenia", w którym coraz trudniej o jednoznaczne kryteria wartościowania ${ }^{27}$.

Autorka, trochę chyba inspirując się rozważaniami Nowickiego o spotkaniach w rzeczach, akcentuje spotkanie pokoleń, w tym również poprzez dzieła. Spotkanie pokoleń ma znaczące miejsce w procesach edukacyjnych, gdzie edukatorzy i edukowani zazwyczaj przecież należą do innych pokoleń. Dodatkowo, jeśli włączyć perspektywę

\footnotetext{
$\overline{23}$ Zob. ibidem, s. 108-111.

24 Ibidem, s. 111.

25 Ibidem, s. 112.

26 Zob. U. Ostrowska, Inkontrologia pedagogiczna, [w:] T. Pilch (red.), Encyklopedia pedagogiczna XXI wieku, t. 2, Wydawnictwo Akademickie Żak, Warszawa 2003, s. 324.

27

Zob. ibidem, s. 326.
} 
spotkania poprzez dzieła (głównie teksty), to warto zauważyć, że w edukacji - oprócz obecnych tu i teraz nauczyciela i uczniów - silnie obecni są np. autorzy podręczników, odkrywcy i twórcy teorii naukowych, będących przedmiotem uczenia się, wzory osobowe z przeszłości, opisane w tekstach różnego rodzaju, od podręczników po dzieła literackie. W edukacji ma więc miejsce nieustające spotkanie pokoleń, tymczasem, zdaniem autorki, zachodzi ono z niemałą trudnością, wynikającą głównie z „odrębnych światów wartości” poszczególnych pokolen' ${ }^{28}$.

Ostrowska nie godzi się z idealistycznymi poglądami Bukowskiego (ale także Stefana Kunowskiego i Bogdana Nawroczyńskiego, których podobne myśli przywołuje), wedle których spotkania nie da się zaplanować, że jest ono zaskakujące, raczej rzadkie i że niektórym ludziom może się przez całe życie w ogóle nie wydarzyć. Skłania się ku tezom Nowickiego, który przyjmuje stanowisko bardziej pragmatyczne i rozważa, jak można się racjonalnie przygotować do spotkania; w szczególności Ostrowska podkreśla potrzebę i możliwość projektowania spotkań edukacyjnych ${ }^{29}$.

\section{Możliwości i warunki spotkań w edukacji}

Problematyka edukacyjna - jak łatwo zauważyć - była już znacząco obecna $\mathrm{w}$ prowadzonych powyżej rekonstrukcjach głównych wątków inkontrologii. Nie jest to nic dziwnego, ponieważ chcąc zaprezentować przykłady różnych typów spotkań, przywoływani autorzy wielokrotnie i nader chętnie odwoływali się do przykładów o treści pedagogicznej. Procesy edukacyjne są przecież jednym wielkim spotkaniem i aż dziwne może się wydawać, że spotkanie nie jest tą kategoria, za pomocą której w pedagogice na co dzień analizowane byłyby osobliwości edukacji; w każdym razie nie dzieje się to nazbyt często. Warto więc poddać pod namysł niektóre aspekty edukacji w kontekście spotkania. Nie aspirując do wyczerpania zagadnienia i pozostawiając pole do popisu wszystkim pedagogom, którzy zamierzają rozważać problematykę edukacyjną z perspektywy inkontrologicznej, podejmę tylko kilka kwestii.

28 Zob. ibidem, s. 327-328. 
Jeśli spotkanie - głównie tak, jak je postrzegają Bukowski, Tischner czy Gadacz - jest nasycone emocjami, ukierunkowane na wartości, daje możliwość „przewyższenia siebie”, przyczyniając się znacząco do osobowego rozwoju, to zazwyczaj jest dla danej osoby WAŻNE. Ma więc ogromny potencjał edukacyjny. Dobrze, gdy takie spotkanie (być może $\mathrm{w}$ aspekcie warunków formułowanych przez Bukowskiego należałoby pisać wielką literą: „Spotkanie”) ma miejsce podczas procesów edukacyjnych, gdy np. wytwarza się relacja mistrz-uczeń, gdy pojawia się fascynacja jakimiś postaciami historycznymi czy nawet bohaterami literackimi (by odwołać się do „spotkań w rzeczach”), gdy kształtują się autentyczne, budujące relacje koleżeńskie. Jednakże znaczna część takich spotkań zachodzi poza kontekstami edukacyjnymi i są one najczęściej „edukacyjnie marnotrawione”, a w każdym razie niewykorzystywane w pełni. Pasjei zainteresowania osoby uczącej się w niewielkim stopniu obchodzą edukatorów. Przeczytane i mocno przeżyte lektury, obejrzane filmy lub spektakle, które wywołały wstrząs, napotkani ludzie (spoza środowiska edukacyjnego), z którymi kontakt pozostawił trwały ślad - to wszystko prawie zupełnie nie obchodzi nauczycieli, ponieważ nie mają oni możliwości (a czasem tylko dobrej woli lub wyobraźni), by te ważne (być może: najważniejsze!) doświadczenia osób uczących się potraktować bądź jako sposobności do spotkań, bądź jako "gotowe" spotkania - ze wszystkimi wynikającymi z nich korzyściami. Szkoła nie jest światem uczniów. Ich „świat życia” jest gdzie indziej. Ich „spotkania” nie są spotkaniami, które miałyby znaczenie edukacyjne, a jeśli mają, to nie jest to prawie wcale wykorzystywane przez edukację formalną.

O konieczność wykorzystywania przez szkołę pozaszkolnych doświadczeń uczniów nawoływał ponad ćwierć wieku temu m.in. Edmund Trempała, pisząc np. „Nieszkolny (równoległy) sektor edukacji (...) nie jest w pełni doceniany przez praktykę oświatową. Znaczna część nauczycieli organizuje proces edukacji szkolnej tak, jakby wychowanie zaczynało się od szkoły oraz ograniczało się tylko do niej i wieku szkolnego. Rzeczywistość edukacyjna jest jednak inna"30.

30 E. Trempała, Edukacja nieszkolna (równoległa) - wprowadzenie, [w:] E. Trempała (red.), Edukacja nieszkolna (równoległa) w warunkach przemian w Polsce, Wydawnictwo Uczelniane Wyższej Szkoły Pedagogicznej, Bydgoszcz 1994, s. 8. 
Podobne stanowisko zajmuje m.in. Zbyszko Melosik, który analizując wzajemne przenikanie się edukacji i popkultury dopomina się o poważne traktowanie uczniowskich pozaszkolnych doświadczeń i włączanie ich w zakres oddziaływań edukacyjnych. Ostrzega: „ignorowanie kultury popularnej jest równoznaczne z ignorowaniem młodzieży i przynosi nieuchronnie ignorowanie pedagogiki przez młodzież" ${ }^{1}$. Ważną kwestią, która na szczęście zaczyna być we współczesnym dyskursie pedagogicznym dostrzegana, jest rosnące znaczenie szkoły jako miejsca, gdzie zachodzi (powinna zachodzić) integracja najrozmaitszych, traktowanych poważnie, oddziaływań, którym podlegają współcześni uczniowie - „cyfrowi tubylcy”. Wówczas pojawi się szansa edukacyjnego wykorzystania również tych spotkań pozaszkolnych, nieformalnych, zaś dla młodych ludzi zazwyczaj ogromnie ważnych.

Potraktowanie kontaktu z drugim człowiekiem jako spotkania (czy raczej spotkania) zakłada konieczność upodmiotowienia partnera interakcji. Jeśli wielu uczniów skarży się, że nie są traktowani przez nauczycieli i wychowawców jako podmioty - to samo można zresztą powiedzieć o relacjach wielu nauczycieli ze swymi zwierzchnikami to już sama świadomość, że dana relacja oznacza, iż spotykam się z drugim człowiekiem, może osłabiać tendencję do uprzedmiotowienia partnera. Oczywiście w każdej relacji, w tym edukacyjnej, następuje kontakt nie „całych” osób, tylko jakichś ich wybranych „fragmentów” czy aspektów - to zjawisko jest przecież dobrze opisane przez socjologię przy użyciu m.in. takich kategorii, jak status czy rola społeczna. Nauczyciel zazwyczaj nie postrzega „całego” ucznia, ze wszystkimi jego uwarunkowaniami rodzinnymi, zdrowotnymi itp., charakterystycznymi cechami, zaletami, wadami, zainteresowaniami, dziwactwami - oprócz tych, zazwyczaj nielicznych, które może jakoś wykorzystać edukacyjnie. Świadomość, że za rolą ucznia stoi „cały” człowiek, osoba, podmiot, jest możliwa do uzyskania, gdy relację edukacyjną potraktuje się jako spotkanie. To samo dotyczy zresztą również relacji ucznia wobec nauczyciela - raczej niezbyt wielu uczniów potrafi dostrzec w nauczycielu „całego” człowieka, raczej ogranicza jego postrzeganie do

31 Z. Melosik, Kultura popularna jako czynnik socjalizacji, [w:] Z. Kwieciński, B. Śliwerski (red.), Pedagogika. Podręcznik akademicki, t. 2, Wydawnictwo Naukowe PWN, Warszawa 2004, s. 90. 
roli „belfra”. Być może jednak jest tak, że traktowanie interakcji jako spotkania i - w konsekwencji - traktowanie partnera jako podmiotu jest możliwe jedynie wówczas, gdy samemu ma się poczucie bycia podmiotem? A więc sytuacja błędnego koła? W każdym razie spotkanie i podmiotowość są ze sobą ściśle powiązane.

Ważną kwestią jest to, co Nowicki określa jako „wzbogacanie mas apercepcyjnych" - rozbudzanie zainteresowań, poszerzanie i pogłębianie wiedzy, ponieważ te „masy” wpływają na to, co podczas spotkania zostanie dostrzeżone. To dotyczy wszelkich relacji edukacyjnych, w tym także - w kontekście uczenia się nieformalnego - tylko potencjalnie edukacyjnych. W przypadku znacznej większości zdarzeń, w których uczestniczymy - w życiu rodzinnym, towarzyskim, zawodowym, działalności hobbystycznej - nie jesteśmy w stanie w pełni wykorzystać niesionego przez te zdarzenia potencjału edukacyjnego, ponieważ zwyczajnie nie jesteśmy do tego przygotowani, ponieważ nasza wstępna wiedza i orientacja w danej kwestii jest niewystarczająca. Potwierdza to zresztą potoczny sąd: „im więcej wiem, tym więcej zobaczę"; przykładem jest chociażby sytuacja dowolnej podróży - im większą mam wiedzę o różnych uwarunkowaniach odwiedzanego miejsca: geograficznych, przyrodniczych, historycznych, politycznych, kulturowych, religijnych, tym więcej mi to miejsce „mówi”, tym bardziej kontakt z nim mnie wzbogaci w różnych aspektach.

To, że dane miejsce czy sytuacja niosą potencjał edukacyjny nie oznacza jednak, że zostanie on wykorzystany. Potrzebna jest jeszcze chęć uczenia się, jakaś motywacja. W przypadku uczenia się nieformalnego, zachodzącego przy okazji innych działań, chodzi raczej o owe - mówiąc językiem Nowickiego - „masy plastyczne”, o zwyczajną otwartość na nowe doświadczenia, o niezasklepianie się w swojej „sobości” (to z kolei język Tischnera), o niezamykanie się na tę możliwość, że w wyniku danej interakcji coś może się we mnie zmienić. Dzierżymir Jankowski - rozwijając nader interesującą koncepcję autoedukacji - pisze w tym kontekście o postawie autoedukacyjnej, która powinna być kształtowana i rozwijana głównie w szkole, by przynosić korzystne efekty (auto)edukacyjne przez całe życie ${ }^{32}$.

32 Zob. D. Jankowski, Autoedukacja wyzwaniem współczesności, Wydawnictwo Adam Marszałek, Toruń 2000, s. 140-164. 
Oczywiście musi przy tym mieć miejsce - na co zwraca też uwagę Nowicki - swoista dynamiczna równowaga między masami plastycznymi a masami obronnymi; wydaje się wszakże, że niebezpieczeństwo radykalnej zmiany naszego zasobu wiedzy, naszych poglądów, postaw pod wpływem każdego spotkania jest mało prawdopodobne. Mamy raczej tendencję do swoistego konserwatyzmu, do utwierdzania się w już posiadanej wiedzy i przejawianych nastawieniach. Niewątpliwie jednak zawsze konieczny jest krytycyzm wobec docierających nowości, ponieważ zdarza się przecież - głównie ludziom młodym - od czasu do czasu popaść w nadmierną, a bezkrytyczną i nierealistyczną, fascynację jakąś nową ideą, koncepcją, poglądem, co bywa - korzystnym albo i nie - punktem zwrotnym w ich życiu.

\section{Uwagi końcowe}

Wskazywane powyżej możliwe bariery spotkań - jak łatwo zauważyć - dotyczą edukacji formalnej, głównie oświaty, zaś wolne od większości tych słabości wydaje się być uczenie się nieformalne. Malewski stawia teze o „zwrocie paradygmatycznym” w andragogice (i w jakiejś mierze - w ogóle w pedagogice), polegającym na dwu procesach: 1) rosnącym znaczeniu uczenia się kosztem nauczania; 2) istotnym wzroście znaczenia edukacji nieformalnej, kosztem formalnej i pozaformalnej ${ }^{33}$. Jeśli ten autor ma rację - a wiele na to wskazuje - to właśnie procesy uczenia się nieformalnego, przy okazji wykonywania czynności innych niż czysto edukacyjne, dają szanse zaistnienia efektywnych spotkań.

Lecz z punktu widzenia pedagogicznego sprawę należy rozpatrywać na odwrót - to spotkania zachodzące w różnych życiowych sytuacjach niosą niebagatelne możliwości (nieformalnego) uczenia się. Tym bardziej, że w edukacji nieformalnej znika sztywny podział na nauczycieli i uczniów; jeśli te terminy są tu w ogóle przydatne, to raczej należy je opatrywać cudzysłowami i traktować metaforycznie. Podczas spotkania obaj jego uczestnicy mają możliwość być dla siebie nawzajem „nauczycielami” i „uczniami”; nawet jeśli nie w jednakowym stopniu, to jednak obaj na siebie wpływają. Mniejszą możliwość tej wzajemności niosą „spotkania w rzeczach” - by użyć terminologii Nowickiego, czy

33 Zob. M. Malewski, Od nauczania do uczenia się..., s. 46-48. 
„spotkania” będące efektem korzystania z mass mediów. Jednakże jeśli nawet nie ma owej wzajemności, to pozostają inne ważne aspekty spotkania, jak m.in.: otwartość (konieczność otwarcia się), emocjonalność, pobudzenie do refleksji, a także owo „przewyższenie siebie” - spotkanie otwiera bowiem możliwość wzrastania ku wartościom, czy po prostu zwykłego rozwoju.

\begin{abstract}
The article presents the possibilities of analysing communication processes occurring in education from the perspective of ,incontrology", i.e. the theory of meetings. The concepts of Andrzej Nowicki and Jerzy Bukowski, as well as other thinkers, regarding the essence of the meeting were presented. Then, the possibilities and conditions of educational meetings were analysed, especially in informal education.
\end{abstract}

\title{
Bibliografia
}

Bukowski J., Zarys filozofii spotkania, Wydawnictwo Znak, Kraków 1987. Gadacz T., Wychowanie jako spotkanie osób, [w:] F. Adamski (red.), Człowiek, wychowanie, kultura. Wybór tekstów, Wydawnictwo WAM, Kraków 1993.

Jankowski D., Autoedukacja wyzwaniem współczesności, Wydawnictwo Adam Marszałek, Torun 2000.

Koć-Seniuch G., Dialog, [w:] T. Pilch (red.), Encyklopedia pedagogiczna XXI wieku, t. 1, Wydawnictwo Akademickie Żak, Warszawa 2003.

Kwieciński Z., Socjopatologia edukacji, Mazurska Wszechnica Nauczycielska, Olecko 1995.

Malewski M., Od nauczania do uczenia się. O paradygmatycznej zmianie $w$ andragogice, Wydawnictwo Naukowe Dolnośląskiej Szkoły Wyższej, Wrocław 2010.

Melosik Z., Kultura popularna jako czynnik socjalizacji, [w:] Z. Kwieciński, B. Śliwerski (red.), Pedagogika. Podręcznik akademicki, t. 2, Wydawnictwo Naukowe PWN, Warszawa 2004.

Nowicki A., Człowiek w świecie dzieł, PWN, Warszawa 1974.

Nowicki A., Spotkania w rzeczach, PWN, Warszawa 1991.

Ostrowska U., Inkontrologia pedagogiczna, [w:] T. Pilch (red.), Encyklopedia pedagogiczna XXI wieku, t. 2, Wydawnictwo Akademickie Żak, Warszawa 2003.

Tischner J., Myślenie według wartości, Wydawnictwo Znak, Kraków 2000. 
Trempała E., Edukacja nieszkolna (równoległa) - wprowadzenie, [w:] E. Trempała (red.), Edukacja nieszkolna (równoległa) w warunkach przemian w Polsce, Wydawnictwo Uczelniane Wyższej Szkoły Pedagogicznej, Bydgoszcz 1994.

Ustawa z dnia 22 grudnia 2015 r. o Zintegrowanym Systemie Kwalifikacji (Dz.U. 2016, poz. 64, z późn. zm.).

Walczak P., Wychowanie jako spotkanie. Józefa Tischnera filozofia człowieka jako źródło inspiracji pedagogicznych, Oficyna Wydawnicza „Impuls”, Kraków 2007. 